\title{
PROLONGED SLOW EXPIRATION (PSE) AND PRONE POSITION INTERVENTION IN CHILDREN : A LITERATURE REVIEW
}

\section{Permaida Mai*1 Fushen ${ }^{1,2}$}

1. Faculty of Medicine and Health Sciences, Krida Wacana Christian University, West Jakarta, Indonesia

2. Krida Wacana Christian University Hospital, West Jakarta, Indonesia

\section{Article Information}

Received: 19 September 2020

Revised: 28 November 2020

Accepted: 29 June 2021

\section{*Corresponding Author}

Permaida Mai

permaida.simanjuntak@ukrida.ac.id

\section{DOI}

10.20884/1.jks.2021.16.2.1532

\begin{abstract}
Nursing interventions to reduce the impact of respiratory problems in children aged $<24$ months in inpatient rooms are not only a science but also an art. This study aimed to determine the effectiveness of Prolonged Slow Expiration (PSE) and prone position in improving respiratory function in hospitalized children aged $<24$ months with respiratory distress in inpatient rooms. This literature review examined thirteen peer-reviewed journals based on inclusion criteria. The results of the review showed that PSE and prone position can reduce the respiratory frequency, maintain the neuromechanical diaphragm, and increase tidal volume. PSE was more effective at lowering the bronchiolitis scale score, preventing the child from experiencing moderate to severe respiratory distress, and decreasing relative sputum production. The prone position is more effective in increasing $\mathrm{SaO} 2$ even when using mechanical ventilation (MV), can increase maximal inspiratory pressure (MIP) and tissue oxygenation index (TOI), provides sleeping comfort, improves cardiorespiratory function, reduces moderate to severe respiratory distress, and can perform intubation. It can be concluded that PSE is a safe and easy therapy to administer to mild respiratory distress patients but has not a significant effect on children $<24$ months with moderate to severe respiratory distress in inpatient rooms.
\end{abstract}

Keywords: Children < 24 months; Prolonged Slow Expiratory (PSE); prone position; respiratory distress

\section{INTRODUCTION}

Currently, children are susceptible to various diseases. UNICEF (2019) stated that respiratory problems are the main cause of death in children in poor and developing countries. Nayani et al. (2018) supported the nation and reported that respiratory problems were the global death in children aged under 5 years. In Indonesia, respiratory distress was the second health problem in $4.4 \%$ or $1,017,290$ children (Kemenkes RI, 2019). Generally, child respiratory problems are caused by immaturity of the lungs of premature babies and respiratory infections that originate from various pathogens that attack the trachea, bronchi, bronchioles, and alveoli followed by severity ranging from mild to severe (Orloff et al., 2019) (Rahmawati et al., 2020).
It is important for nurses to provide independent interventions for children to reduce respiratory distress (Baudin et al., 2019). Interventions given to neonates, infants, and toddlers aim to prevent disturbances in airway clearance, ineffective breathing patterns, and increased oxygenation (Puji, 2018). The interventions are provided with a therapeutic technique through prolonged slow expiration (PSE) (Nogueira et al., 2019) and the prone position (Cheifetz, 2017).

PSE and prone position are non-pharmacological therapies that can be given to children which are not only a science but also an art in independent nursing practice (Liu et al., 2018). PSE is nonpharmacological-advanced chest physiotherapy that can stimulate children's diaphragm to clear the lungs from secretions and increase oxygenation 
(Mishra et al., 2020). The prone position is a nonpharmacological action that can improve the lung mechanism to increase oxygenation (Orloff et al., 2019). Both PSE therapy and prone position provide benefits in maintaining lung expansion and increasing oxygenation in children (Schaan et al., 2020).

This literature review aims to distinguish both interventions and determine the best time when nurses can provide both therapies to children. We have not found published literature discussing the benefits and effectiveness of PSE therapy and the prone position in hospitalized children aged $<24$ months with respiratory distress in inpatient wards. Therefore, it is considered necessary to synthesize published evidence of the effectiveness of PSE therapy and prone position and explain the indications of both therapies in dealing with children's respiratory distress aged $<24$ months in inpatient wards (Liu et al., 2018).

\section{METHOD}

Study design

This is a literature review of the effectiveness of Prolonged Slow Expiratory (PSE) therapy and prone position in children aged $<24$ months with respiratory distress in inpatient wards. The development of the research question follows the PICO guideline as presented in Table 1 below.

Table 1. PICO

Research Title PICO questions
Prolonged Slow Expiration (PSE) and Prone Position Intervention in Children

1. Children Under 24 Months with Respiratory Distress in Inpatient Rooms, What Is the Effect of Prolonged Slow Expiration (PSE) Compared to The Prone Position on Respiratory Tract Function?

2. Are there any changes in respiratory function when given Prolonged Slow Expiration (PSE) compared with the prone position in Children Under 24 Months with Respiratory Distress in Inpatient Rooms?

\begin{tabular}{|c|c|c|c|c|c|c|c|c|}
\hline $\begin{array}{c}\text { Research } \\
\text { topics }\end{array}$ & & $\begin{array}{c}\mathbf{P} \\
\text { (POPULATION) }\end{array}$ & & $\begin{array}{c}\text { I } \\
\text { (INTERVENTION) }\end{array}$ & & $\begin{array}{c}\text { C } \\
\text { (COMPARATION) }\end{array}$ & & $\begin{array}{c}\text { O } \\
\text { (OUTCOME) }\end{array}$ \\
\hline Key Term & & $\begin{array}{l}\text { “Children Under } \\
24 \text { Months with } \\
\text { Respiratory } \\
\text { distress in } \\
\text { Inpatient } \\
\text { Rooms" }\end{array}$ & AN & $\begin{array}{l}\text { "Prolonged Slow } \\
\text { Expiration" }\end{array}$ & AN & "Prone Position" & AN & $\begin{array}{l}\text { "Respiratory } \\
\text { Function" }\end{array}$ \\
\hline Alternative Term & OR & $\begin{array}{l}\text { Pediatric with } \\
\text { Respiratory } \\
\text { Distress in } \\
\text { Hospital }\end{array}$ & OR & - & OR & Semi prone & OR & $\begin{array}{l}\text { Respiratory } \\
\text { Rate }\end{array}$ \\
\hline Alternative Term & OR & $\begin{array}{c}\text { Pediatric Acute } \\
\text { Respiratory } \\
\text { Syndrome in } \\
\text { Pediatric } \\
\text { Intensive Care } \\
\text { Unit }\end{array}$ & OR & - & & $\begin{array}{l}\text { Quarter prone } \\
\text { position }\end{array}$ & OR & $\begin{array}{l}\text { Oxygen } \\
\text { saturation }\end{array}$ \\
\hline Alternative Term & OR & $\begin{array}{l}\text { Children with } \\
\text { RDS in } \\
\text { Neonates } \\
\text { Intensive Care } \\
\text { Unit }\end{array}$ & OR & - & & - & OR & $\begin{array}{l}\text { Hard to } \\
\text { breath }\end{array}$ \\
\hline
\end{tabular}

\section{Search Strategy}

Alternative term for population $(P)$ used "Children Under 24 Months with Respiratory Distress in Inpatient Rooms" OR "Pediatric with Respiratory Distress in Hospital" OR "Pediatric Acute Respiratory Syndrome in PICU" OR "Children with RDS in Neonate Intensive Care Unit" OR "Children with Pneumonia in Hospital" OR "Pneumonia in Child" OR "Child with Bronchiolitis in Patient Room" OR "Pediatric with Respiratory Distress in PICU" OR "RDS in Children" OR "Pediatric Acute Lung Injury in PICU" OR "Pediatric with acute respiratory infection in Patient Room; Researchers did not use alternative terms for intervention (I); Alternative terms for comparison (C), researchers used "Semi Prone Position" OR "Quarter Prone Position"; Alternative terms for the outcome $(\mathrm{O})$, researchers used
"Respiratory Rate" OR "Oxygen saturation" OR "Hard to breathe" OR "Oxygenation" OR "Cough with phlegm" OR "Wheezing".

\section{Selection Criteria}

The inclusion criteria of this study included 2012-2020journal collection, quantitative and qualitative researches, using only original research, the full text of children with respiratory distress in children, children who have additional breath sounds, children aged 0 to 24 months, children in the intensive care unit and inpatient rooms, and children receiving PSE therapy and prone position. The exclusion criteria included conference papers, symposia, discussion papers, and children with respiratory arrest. Researchers have described the filters in Flowchart 1. A total of 13 
studies were included in the review, including 5 studies that reviewed PSE and 8 studies that reviewed the prone position.

\section{Flowchart 1. Journal Search Strategy}

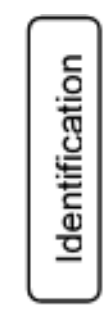

Prolonged Slow Expiration (PSE): Publled $(n=20)$, Sage Pub $(n=755)$, Science Direct $(n=3158)$, Wolter Kluwer $(n=331)$, Taylor \& Francis $(n=837)$ $(n=5,101)$
Prone Position : Science Dired $(n=19970)$, Wolter Kluwer $(n=3837)$, BMC $(n=15059)$, JStor $(n=4890)$, Taylor \& Francis $(n=4059)$, SciELO $(n=196)$ $(n=48,011)$

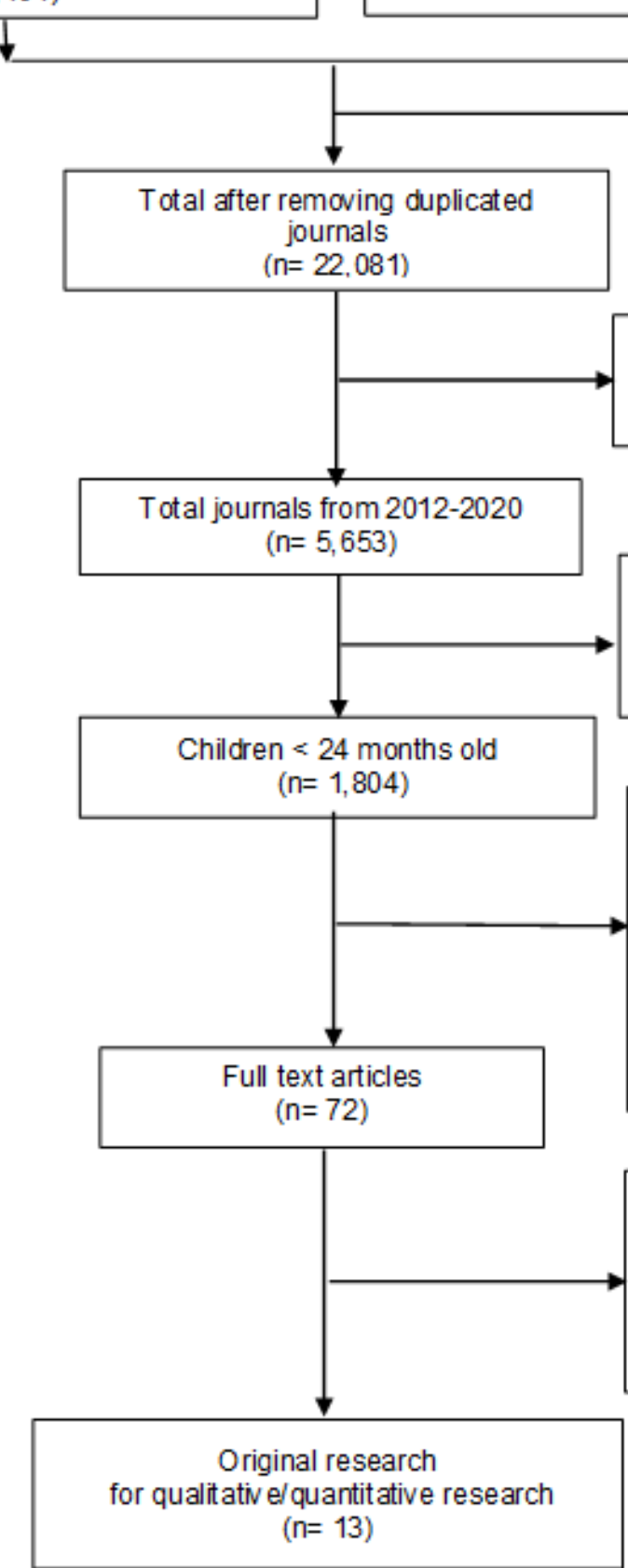

Exclusion criteria: journals published under 2012 $(n=16,428)$

\section{Exclusion criteria:} characteristics of the age of the child over 24 months $(n=3,849)$

Exclusion criteria: incomplete study data; not hospital studies; researches that did not show the value of reliability; abstracts;

conference papers; symposium; discussion papers $(n=1,732)$

Exclusion criteria: literature review, narrative review, systematic review; critical review; metaanalysis $(n=59$

for qualitativ e/quantitative research $n=13$ 


\section{Table 2. Summary of studies}

\section{No Title (Author)}

Design

Case Report

Effect of Prolonged Slow Expiratory Technique as an Adjunct to Pulmonary Rehabilitation in Resolving Pulmonary Congestion in Neonates with Congenital Pneumonia

(Mishra et al., 2020)

2 Oxygenation Instability Assessed by Oxygen Saturation Histograms During Supine Vs Prone Position in Very Low Birthweight Infants Receiving Noninvasive Respiratory Support

(Miller-Barmak et al., 2020)

3 Prolonged Slow Expiration Technique Improves Recovery from Acute Bronchiolitis in Infants: FIBARRIX Randomized Controlled Trial

(Conesa-Segura et al., 2019)

4 Is Prolonged Slow Expiration a Reproducible Airway Clearance Technique?

(Nogueira et al., 2019)

5 Physiological Effect of Prone Position in Randomized Children with Severe Bronchiolitis: A Cross-Over Randomized Cross-Over Study (BRONCHIODV)

(Baudin et al., 2019)

\begin{tabular}{cl}
\hline 6 & $\begin{array}{l}\text { Effects of Prone Sleeping on Cerebral } \\
\text { Oxygenation in Preterm Infants. }\end{array}$ \\
& (Shepherd et al., 2019) \\
\hline 7 & $\begin{array}{l}\text { Semiprone Position is Superior to Supine } \\
\text { Position for Paediatric Endotracheal Intubation } \\
\text { During Massive Regurgitation, A Randomized } \\
\text { Crossover Simulation Trial }\end{array}$ \\
\hline
\end{tabular}

Randomized
Prospective

Crossover,

Observationa

I Study

Controlled

Trial

Cross-

Sectional

Study

Quasy

Experiment

prer

16 children aged 59 weeks, SpO2 > 93\%, no wheezing sound, heart rate 110-140 beats per minute (bpm), had an expiratory volume (ERV)

14 newborns aged 25-58 To see inspiratory effort, days, diagnosed with viral respiratory metabolism, bronchiolitis, hospitalized in diaphragm movement when NICU/PICU, needed for given the prone position versus respiratory support by the supine position in children nCPAP with severe bronchiolitis who use noninvasive ventilation 56 very premature and To determine the effect of semiprone on the fulfillment of lung oxygenation of children's brains while sleeping in the NICU

Randomized 18 children with high-risk To determine the speed of Crossover respiratory distress attached inserting the ETT during the Simulation to endotracheal tube who management of respiratory Trial were treated in the distress in a patient in the semi-

\section{Results}

PSE therapy can stimulate diaphragm and lung movement; minimize the occurrence of pulmonary congestion; effective only in children with mild acute respiratory distress in the NICU.

The prone position did not make the patient apnea and not decrease oxygen saturation.

PSE therapy reduced the severity of acute bronchiolitis; was more effective when combined with inhalation therapy; there was no increase in oxygen saturation.

PSE therapy can reduce mucus production and prevent children from more severe respiratory problems.

The prone position was effective in reducing inspiratory efforts and respiratory metabolism; did not occur in the esophagus; and maintained the neuromechanical efficiency of the diaphragm.

Prone position had an effect in increasing cerebral tissue oxygenation index (TOI), arterial $\mathrm{SaO} 2$, and the child felt comfortable and did not fuss while sleeping.

Management of respiratory distress during intubation in the semi-prone position was more effective than the supine position; researchers experienced the ease of clearing the airway. 


\begin{tabular}{|c|c|c|c|c|c|}
\hline No & Title (Author) & Design & Samples & Aim & Results \\
\hline & (Fevang et al., 2018) & & NICU/PICU rooms & $\begin{array}{l}\text { prone position, compared with } \\
\text { the supine position }\end{array}$ & \\
\hline 8 & $\begin{array}{l}\text { Comparison of Respiratory Status Between } \\
\text { Semi- Fowler and Elevated Prone Position } \\
\text { Among Under } 5 \text { Years Old Children with Acute } \\
\text { Respiratory Tract Infection in Ibrahim Malik } \\
\text { Hospital Sudan } \\
\text { (Elhussain et al., 2018) }\end{array}$ & $\begin{array}{l}\text { Prospective } \\
\text { Based Study }\end{array}$ & $\begin{array}{l}401 \text { children aged }<5 \text { years } \\
\text { with grouped acute } \\
\text { respiratory tract infections } \\
(\mathrm{ARI})\end{array}$ & $\begin{array}{l}\text { To assess the respiratory rate } \\
\text { (RR) between the prone versus } \\
\text { semi-fowler positions }\end{array}$ & $\begin{array}{l}\text { The prone position had a greater effect on } \\
\text { neonates and infants than toddlers with severe } \\
\text { respiratory distress in reducing the respiratory } \\
\text { frequency. }\end{array}$ \\
\hline 9 & $\begin{array}{l}\text { The Quarter Prone Position Increases Oxygen } \\
\text { Saturation in Premature Infants Using } \\
\text { Continuous Positive Airway Pressure } \\
\text { (Utario et al., 2017) }\end{array}$ & $\begin{array}{l}\text { Randomized } \\
\text { Controlled } \\
\text { Trial with } \\
\text { Crossover } \\
\text { Design }\end{array}$ & $\begin{array}{l}15 \text { premature babies treated } \\
\text { in the NICU room with } \\
\text { pulmonary immaturity }\end{array}$ & $\begin{array}{l}\text { To measure the benefits of the } \\
\text { quarter prone position on the } \\
\text { oxygenation status of preterm } \\
\text { infants using CPAP in NICU }\end{array}$ & $\begin{array}{l}\text { The quarter prone position was effective for } \\
\text { improving oxygenation status even when using } \\
\text { CPAP. }\end{array}$ \\
\hline 10 & $\begin{array}{l}\text { A Randomized Clinical Trial to Assess the } \\
\text { Effectiveness of Prone Position on } \\
\text { Cardiorespiratory Outcomes Among Infants } \\
\text { with Respiratory Distress } \\
\text { (Sharma et al., 2016) }\end{array}$ & $\begin{array}{l}\text { Randomized } \\
\text { Clinical Trial }\end{array}$ & $\begin{array}{l}60 \text { babies in childcare units } \\
\text { (NICU, PICU, and post-ICU) }\end{array}$ & $\begin{array}{l}\text { To assess and compare the } \\
\text { effect of the prone and supine } \\
\text { positions on cardiorespiratory } \\
\text { outcomes among infants with } \\
\text { respiratory distress and to } \\
\text { investigate complications of } \\
\text { prone position administration }\end{array}$ & $\begin{array}{l}\text { The prone position was effective for improving } \\
\text { cardiorespiratory function and reducing } \\
\text { moderate levels of respiratory distress. }\end{array}$ \\
\hline 11 & $\begin{array}{l}\text { Impact of The Prolonged Slow Expiratory } \\
\text { Maneuver on Respiratory Mechanics in } \\
\text { Wheezing Infants } \\
\text { (Lanza et al., 2013) }\end{array}$ & $\begin{array}{l}\text { Cross- } \\
\text { Sectional } \\
\text { Study }\end{array}$ & 18 babies aged $4-24$ months & $\begin{array}{l}\text { To determine the effect of three } \\
\text { maneuvers (maneuver A PSE, } \\
\text { maneuver B PSE, and } \\
\text { maneuver C PSE) on breathing }\end{array}$ & $\begin{array}{l}\text { This breathing therapy technique was able to } \\
\text { induce significant changes in VT (Tidal } \\
\text { Volume) and RR (Respiratory Rate) in infants } \\
\text { with repeated wheezing, even without } \\
\text { exacerbations. }\end{array}$ \\
\hline 12 & $\begin{array}{l}\text { Chest Physical Therapy Is Effective in } \\
\text { Reducing the Clinical Score in Bronchiolitis: } \\
\text { Randomized Controlled Trial } \\
\text { (Gomes et al., 2012) }\end{array}$ & $\begin{array}{l}\text { Randomized } \\
\text { Controlled } \\
\text { Trial }\end{array}$ & $\begin{array}{l}30 \text { babies aged } 28 \text { days to } \\
24 \text { months, infants with } \\
\text { respiratory syncytial virus } \\
\text { (RSV), and infants with } \\
\text { acute viral bronchiolitis } \\
\text { (AVB) }\end{array}$ & $\begin{array}{l}\text { To evaluate the effectiveness of } \\
\text { chest physical therapy (nCPT } \\
\text { chest physical therapy with new } \\
\text { techniques, PSE and CRR) in } \\
\text { reducing the clinical score in } \\
\text { infants with acute viral } \\
\text { bronchiolitis (AVB) }\end{array}$ & $\begin{array}{l}\text { There was a decrease in the respiratory rate } \\
\text { for } 24 \text { hours and the children were able to } \\
\text { breathe normally again after } 72 \text { hours of } \\
\text { receiving PSE therapy. } \\
\text { There was an increase in oxygen saturation } \\
\text { after } 72 \text { hours of treatment. } \\
\text { Wang's clinical score showed the } \\
\text { effectiveness of nCPT therapy in children with } \\
\text { bronchiolitis. }\end{array}$ \\
\hline 13 & $\begin{array}{l}\text { Influence of Prone Position on Oxigenation, } \\
\text { Respiratory Rate and Muscle Strength in } \\
\text { Preterm Infants Being Weaned from } \\
\text { Mechanical Ventilation } \\
\text { (Malagoli et al., 2012) }\end{array}$ & $\begin{array}{l}\text { Cross- } \\
\text { Sectional } \\
\text { Study }\end{array}$ & $\begin{array}{l}45 \text { babies with gestation age } \\
\text { ranged from } 26 \text { to } 34 \text { weeks, } \\
\text { body weight was > } 1500 \\
\text { grams, evaluated for } \\
\text { respiratory distress }\end{array}$ & $\begin{array}{l}\text { To see the effect of the prone } \\
\text { position on the breathing force, } \\
\text { oxygenation, and breathing rate } \\
\text { between the prone position and } \\
\text { the supine position }\end{array}$ & $\begin{array}{l}\text { The prone position for the neonate in the NICU } \\
\text { can increase the SpO2 but cannot decrease } \\
\text { respiratory rate. }\end{array}$ \\
\hline
\end{tabular}


Diagram 1. Stages of PSE therapy implementation and prone position in children aged $<24$ months with respiratory distress

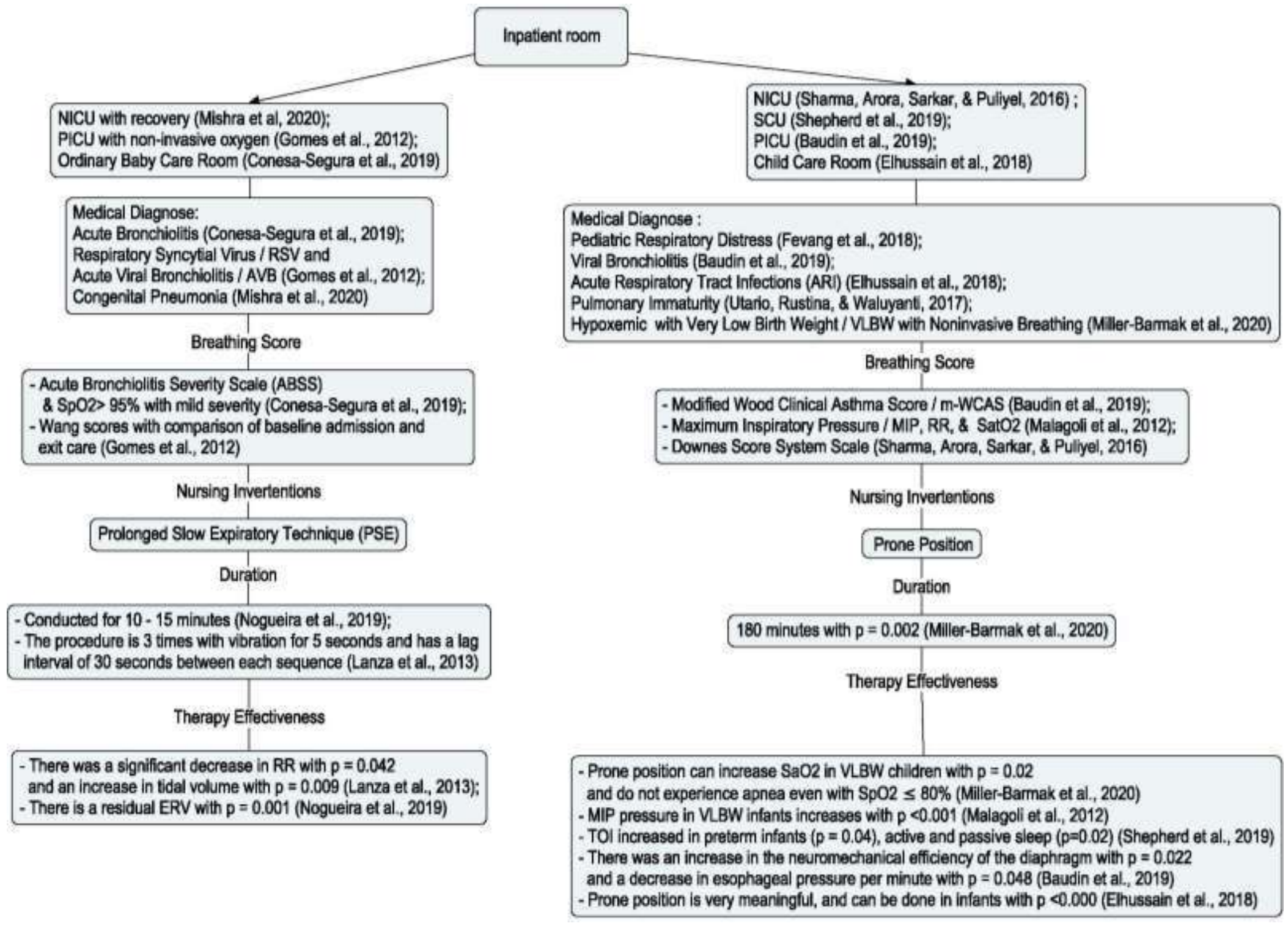




\section{RESULT}

The incidence of respiratory distress in children aged less than 24 months is still high in poor and developing countries. Kemenkes $\mathrm{RI}$ (2019) reported that one of the causes of the high mortality rate in children is due to respiratory disorders in children, therefore it is noteworthy to implement independent nursing interventions to improve lung function in children (Mishra \& Samuel, 2018). After selecting journals based on the inclusion and exclusion criteria, it was retrieved 13 articles published in 2012-2020 were included in this review. Table 2 shows the data extraction of the articles.

Research studies on the provision of Prolonged Slow Expiratory (PSE) therapy and prone position can be given to children aged $<24$ months with respiratory problems. PSE therapy is usually given to infants aged 0 to less than 24 months of age who experience improvement in oxygen saturation and generally it is for children who undergo care in the neonatal intensive care unit (NICU) and high care unit (HCU) (Mishra \& Samuel, 2018). Nurses need to remember that giving this therapy aims to clear the patient's airway due to an excess secretion (Mishra \& Samuel, 2018) and they must pay attention to the anatomy, physiology, and psychology of children (Bellanti \& Settipane, 2018). Giving PSE can not only be given to children who have mild respiratory distress but also to the patient's hemodynamic within normal limits (Mishra et al., 2020). PSE can be combined with another chest physiotherapy to reduce the amount of sputum (Conesa-Segura et al., 2019), can increase tidal volume, and reduce the respiratory rate so that it does not obstruct the patient's airway (Lanza et al., 2013).
Giving the prone position to children aged $<24$ months with respiratory distress due to lung immaturity in premature babies, early acute lung injury, and infections caused by bacteria and viruses such as pneumonia, bronchiolitis, and COVID-19, actually provides benefits because it can increase oxygen saturation even after using a mechanical ventilator. However, this position should be stopped when $\mathrm{PaO} 2 / \mathrm{FiO} 2 \geq 150$; OI < 12; OSI < 10 in children suffering from COVID-19 (Kneyber et al., 2020). The prone position can also reduce the respiratory rate in children (Elhussain et al., 2018), Tissue Oxygenation Index (TIO), make better quality of sleep (Shepherd et al., 2019), prevent diuresis, and maintain fluid balance in children (Dall' Agnese et al., 2019), as well as increase the neuromechanical efficiency of the diaphragm, decrease esophageal pressure (Baudin et al., 2019), and decrease maximal inspiratory pressure (MIP) so as not to obstruct the patient's breathing (Malagoli et al., 2012) (Table 2).

Before implementation, nurses also need to know the medical diagnosis, respiratory measurement scale, duration, and effectiveness of each therapy for the patient's body (Diagram 1).

\section{DISCUSSION}

Acute respiratory disorders of children in intensive inpatient rooms every year amounted to $14.46 \%$. The nurse's inability to think critically can lead to worsening child conditions (Yin et al., 2016). Of the 13 studies that have been reviewed, it was proven the effectiveness of PSE therapy and prone position to improve the respiratory status of hospitalized children aged $<24$ months in inpatient rooms. In this study, researchers have also attempted to develop steps to make it easier for nurses to provide PSE and prone position therapy based on literature searches and can be seen in Table 3.

Table 3. Procedure for PSE and prone position

\begin{tabular}{|c|c|c|}
\hline Action & Definition and Work Steps & $\begin{array}{l}\text { Indications and } \\
\text { Contraindications }\end{array}$ \\
\hline $\begin{array}{l}\text { Prolonged Slow } \\
\text { Expiratory (PSE) }\end{array}$ & $\begin{array}{l}\text { The newest chest physiotherapy technique used in clinical } \\
\text { practice in hypersecretory children to remove secretions and } \\
\text { reduce hyperventilation (Nogueira et al., 2019). } \\
\text { PSE work steps (Mishra et al., 2020): } \\
\text { a. Provide information and education to parents prior to } \\
\text { action and prepare equipment before action is taken. } \\
\text { b. Wash hands before action. } \\
\text { c. The patient is positioned in a supine position in a } \\
\text { comfortable condition and the vital signs are normal, the } \\
\text { body is relaxed, and the patient's behavior is calm. } \\
\text { d. During the procedure, place one hand over the chest } \\
\text { cavity and the other hand over the abdominal cavity, just } \\
\text { above the umbilicus. } \\
\text { e. In the final expiration phase, the therapist exerts a } \\
\text { compressive force from the hypothenar (palm) and at the } \\
\text { same time presses from the upper hand (the hand above } \\
\text { the chest cavity), and gives pressure from the lower hand } \\
\text { (the hand above the abdominal cavity). } \\
\text { f. This compression is maintained for } 4-5 \text { seconds followed } \\
\text { by slow release. } \\
\text { g. One set of three compressions is given three times with a } \\
\text { pause of } 30 \text { seconds between each compression. }\end{array}$ & $\begin{array}{l}\text { Indications: } \\
\text { a. Reducing the secretion } \\
\text { of sputum in the child's } \\
\text { body } \\
\text { b. Can be given to } \\
\text { children with "repeated } \\
\text { wheezing" } \\
\text { Contraindications: } \\
\text { a. Cannot be given to } \\
\text { children with airway } \\
\text { obstruction } \\
\text { Cannot be given to } \\
\text { infants with } \\
\text { gastroesophageal } \\
\text { reflux disease, babies } \\
\text { who have undergone } \\
\text { thoracic and/or } \\
\text { abdominal surgery and } \\
\text { have been diagnosed } \\
\text { with heart disease or } \\
\text { neuropathy }\end{array}$ \\
\hline
\end{tabular}




\begin{tabular}{|c|c|c|}
\hline Action & Definition and Work Steps & $\begin{array}{l}\text { Indications and } \\
\text { Contraindications }\end{array}$ \\
\hline Prone Position & $\begin{array}{l}\text { This is a simple action by reversing the patient's body position to } \\
\text { increase oxygenation throughout the patient's body, especially } \\
\text { in patients with respiratory disorders and hypoxemia } \\
\text { (Jagadeeswari \& Soniya, 2020). } \\
\text { The work steps of prone position (Guérin et al., 2013): } \\
\text { a. Provide information and education to parents before taking } \\
\text { action and prepare equipment before action. } \\
\text { b. Assess the patient's condition from oxygen saturation, } \\
\text { respiration rate, lung roentgen in the patients, and make } \\
\text { sure the length of the ventilator circuit according to patient } \\
\text { needs. } \\
\text { Check the fit of the endotracheal tube and NGT/OGT tube } \\
\text { and protect the patient's knees, forehead, chest, and iliac } \\
\text { crest to prevent pressure sores. } \\
\text { d. Keep nurses clean by washing hands before taking action. } \\
\text { e. Work with } 3 \text { to } 4 \text { nurses to change the patient to a prone } \\
\text { position to maintain the patient's head, endotracheal tube, } \\
\text { and ventilator. } \\
\text { Be sure to take priority direction of the patient's central } \\
\text { vein when turning the patient over. } \\
\text { g. The patient is transferred to the sagittal plane and remains } \\
\text { in this position for a while. The goal is to make it easier to } \\
\text { attach the heart electrodes to its back and attach a base to } \\
\text { prevent the risk of pressure sores. }\end{array}$ & $\begin{array}{l}\text { Indications: } \\
\text { a. Can be given to } \\
\text { patients who have } \\
\text { moderate to severe } \\
\text { ARDS } \\
\text { b. Can be given to } \\
\text { children using MV } \\
\text { (mechanical ventilation) } \\
\text { Contraindications: } \\
\text { Cannot be done in } \\
\text { children with post- } \\
\text { thoracic surgery, } \\
\text { tracheostomy, patients } \\
\text { receiving renal and } \\
\text { abdominal therapy } \\
\text { Patients with a history } \\
\text { of congenital heart } \\
\text { disease and } \\
\text { Intraventricular } \\
\text { Hemorrhage (IVH) }\end{array}$ \\
\hline
\end{tabular}

The review of PSE therapy noted that there was an increase in tidal volume in children during treatment at the NICU and HCU. Sound "wheezing" was reduced in both lungs and the lungs did not experience an exacerbation. PSE therapy was able to stimulate the release of sputum in children over 12 months of age and can reduce the respiratory rate in children with congenital pneumonia when it was given routinely within 24 hours of treatment. In addition, newborns who have respiratory problems can also be given PSE therapy as long as they use non-invasive oxygen devices such as nasal canula oxygen with an APGAR value $>7$ for 5 minutes and 10 minutes of birth, and have stable child vital signs. The children were calm and oxygen saturation > 96\% or within normal limits. PSE therapy can be combined with other chest physiotherapies such as clapping and postural drainage to remove thick and reduce pain in the chest cavity when it is expelled. PSE therapy can also be done with other methods of nCPT (PSE, retrograde rhino-pharyngeal cleaning chest physiotherapy technique) and it was proven of no side effects in children. A measurement to see the effectiveness of PSE therapy can be done before and after the use of the Wang Score or CS by comparing the results before and after therapy. The prone position also provides benefits to children aged $<24$ months who experience respiratory problems, i.e., reducing child pneumonia from moderate to severe pneumonia and increasing $\mathrm{SpO} 2$ from $\leq$ $80 \%$ to $>94 \%$ of children with very low birth weight (VLBW) in premature babies, as well as preventing apnea and reducing the frequency of breathing when the children experiencing hyperpnea (Elhussain et al., 2018).

The limitation of this study is only generally reviewing the effects of PSE therapy and prone position on respiratory function in hospitalized children aged under 24 months with respiratory distress in inpatient rooms. Further reviews are expected to evaluate which therapies give the best result when hospitalized children aged $<24$ months experience respiratory distress in inpatient rooms.

\section{CONCLUSION AND RECOMMENDATION}

PSE therapy and prone position are effective in reducing the respiratory frequency and improving lung function to speed up the healing process in children aged $<24$ months with respiratory distress, and therefore this is a recommended nursing intervention in pediatric wards. It is worth noting that both therapies are also safe and have no side effects. However, PSE therapy can only be applied to children with normal vital signs and showing mild respiratory distress symptoms, while the prone position can be applied to a more varied condition. In addition, the provision of PSE therapy will be more effective when combined with other types of chest physiotherapies while the prone position does not require a combination of other actions. In practice, PSE is an active intervention that is only given for a certain period of time, while the prone position can be done for a longer time.

\section{REFERENCES}

Baudin, F., Emeriaud, G., Essouri, S., Beck, J., Portefaix, A., Javouhey, E., \& Guerin, C. (2019). Physiological effect of prone position in children with severe bronchiolitis: A randomized cross-over study (BRONCHIO-DV). Journal of Pediatrics, 205, 112119.e4. https://doi.org/10.1016/j.jpeds.2018.09.066

Bellanti, J. A., \& Settipane, R. A. (2018). Children are not small adults. Allergy and Asthma Proceedings, 39(4), 261-263. https://doi.org/10.2500/aap.2018.39.4156

Cheifetz, I. M. (2017). Pediatric ARDS. Respiratory Care, 62(6), 718-731. https://doi.org/10.4187/respcare.055 91

Conesa-Segura, E., Reyes-Dominguez, S. B., Ríos-Díaz, J., Ruiz-Pacheco, M. Á., Palazón-Carpe, C., \& SánchezSolís, M. (2019). Prolonged slow expiration technique improves recovery from acute bronchiolitis in infants: FIBARRIX randomized controlled trial. Clinical Rehabilitation, 33(3), 504-515. https://doi. org/10.1177/0269215518809815 
Dall' Agnese, R. M. F., de Oliveira Filho, P. F., Costa, C. A. D., Tonial, C. T., Bruno, F., Enloft, P. R., Fiori, H. H., \& Garcia, P. C. R. (2019). Fluid balance in pediatric patients in prone position: A pragmatic study. Revista Da Associacao Medica Brasileira, 65(6), 839-844. https://doi.org/10.1590/1806-9282.65.6.839

Elhussain, M. Y. O., Massad, H. K. A. A., \& Mohammed, S.S. (2018). Comparison of respiratory status between semi- fowler and elevated prone position among under 5 years old children with acute respiratory tract infection in ibrahim malik hospital sudan. 4(2), 10-14.

Rahmawati, E.,Anggraeni, D.,M., \& Setiyowati, E. (2020). Cesarean delivery and respiratory distress syndrome in late preterm infants. Caring: Indonesian Journal of Nursing Science, 2(2). https://doi.org/10.32734/ijns.v $2 \mathrm{i} 2.4969$

Fevang, E., Haaland, K., Røislien, J., \& Bjørshol, C. A. (2018). Semiprone position is superior to supine position for paediatric endotracheal intubation during massive regurgitation, a randomized crossover simulation trial. BMC Anesthesiology, 18(1). https://doi.org/10.1186/s12871-018-0474-z

Gomes, É. L. F. D., Postiaux, G., Medeiros, D. R. L., Monteiro, K. K. D. S., Sampaio, L. M. M., \& Costa, D. (2012). Chest physical therapy is effective in reducing the clinical score in bronchiolitis: randomized controlled trial $A$ fisioterapia respiratória é eficaz na redução de escore clínico na bronquiolite: ensaio controlado randomizado. Rev Bras Fisioter, 1616(33), 241-7241.

Guérin, C., Reignier, J., Richard, J.-C., Beuret, P., Gacouin, A., Boulain, T., Mercier, E., Badet, M., Mercat, A., Baudin, O., Clavel, M., Chatellier, D., Jaber, S., Rosselli, S., Mancebo, J., Sirodot, M., Hilbert, G., Bengler, C., Richecoeur, J., ... Ayzac, L. (2013) Prone positioning in severe acute respiratory distress syndrome. New England Journal of Medicine, 368(23), 2159-2168. https://doi.org/10.1056/nejmoa 1214103

Jagadeeswari, J., \& Soniya, R. (2020). Effectiveness of prone and supine position on respiratory pattern among neonates. Drug Invention Today, 13(7), 983985.

Kemenkes RI. (2019). Hasil Riset Kesehatan Dasar Tahun 2018. Kementrian Kesehatan RI, 53(9), 1689-1699.

Kneyber, M. C. J., Medina, A., Alapont, V. M. i, Brierly, J., Chidini, G., Cusco, M. G., Hammer, J., Fernandez, Y. M. L., Camilo, C., Milesi, C., Luca, D. de, Pons, M., Tume, L., \& Rimensberger, P. C. (2020). Practice recommendations for the management of children with suspected or proven COVID-19 infections from the Paediatric Mechanical Ventilation Consensus Conference (PEMVECC) and the section respiratory failure from the european society for paediatric a. European Society for Pediatric and Neonatal Intensive Care, 1-7.

Lanza, F. de C., Wandalsen, G. F., Cruz, C. L. da, \& Solé, D. (2013). Impact of the prolonged slow expiratory maneuver on respiratory mechanics in wheezing infants. Jornal Brasileiro de Pneumologia: Publicacao Oficial Da Sociedade Brasileira de Pneumologia e Tisilogia, 39(1), 69-75. https://doi.org /10.1590/S1806-37132013000100010
Liu, Y., He, C., Li, H., Xu, F., Feng, L., \& Xie, H. (2018). Application of comprehensive airway nursing management in the treatment of children with respiratory tract infections. International Journal of Clinical and Experimental Medicine, 11(9), 98999904.

Malagoli, R. de C., Santos, F. F. A., Oliveira, E. A., \& Bouzada, M. C. F. (2012). Influence of prone position on oxigenation, respiratory rate and muscle strength in preterm infants being weaned from mechanical ventilation. Revista Paulista de Pediatria, 30(2), 251256. https://doi.org/10.1590/S0103-05822012000200 015

Miller-Barmak, A., Riskin, A., Hochwald, O., Haddad, J., Dinur, G., Vortman, R., Kugelman, A., \& BorensteinLevin, L. (2020). Oxygenation instability assessed by oxygen saturation histograms during supine vs prone position in very low birthweight infants receiving noninvasive respiratory support. Journal of Pediatrics, 226, 123-128. https://doi.org/10.1016/j.jp eds.2020.06.066

Mishra, R., Dasgupta, A., \& Samuel, A. (2020). Effect of prolonged slow expiratory technique as an adjunct to pulmonary rehabilitation in resolving pulmonary congestion in neonates with congenital pneumonia. Journal of Clinical Neonatology, 9(1), 82. https://doi.o rg/10.4103/jcn.jcn_22_19

Mishra, R., \& Samuel, A. (2018). Prolonged slow expiratory technique: A lung clearance technique for neonates admitted in neonatal intensive care units. Journal of Clinical Neonatology, 7(4), 282. https://doi.org/10.410 3/jcn.jcn_44_18

Nayani, K., Naeem, R., Munir, O., Naseer, N., Feroze, A., Brown, N., \& Mian, A. I. (2018). The clinical respiratory score predicts paediatric critical care disposition in children with respiratory distress presenting to the emergency department. BMC Pediatrics, 18(1), 1-8. https://doi.org/10.1186/s12887 -018-1317-2

Nogueira, M. C. P., Ribeiro, S. N. S., Silva, É. P., Guimarães, C. L., Wandalsen, G. F., Solé, D., \& Lanza, F. C. (2019). Is prolonged slow expiration a reproducible airway clearance technique?. Physical Therapy, 99(9), 1224-1230. https://doi.org/10.1093/p $\mathrm{tj} / \mathrm{pzz} 080$

Orloff, K. E., Turner, D. A., \& Rehder, K. J. (2019). The current state of pediatric acute respiratory distress syndrome. Pediatric, Allergy, Immunology, and Pulmonology, 32(2), 35-44. https://doi.org/10.1089/p ed.2019.0999

Puji, L. (2018). Quarter turn from prone position increases oxygen saturation in premature babies with respiratory distress syndrome. 13(1), 38-44.

Schaan, C. W., de Souza Vieira, V., Miller, C., Peiter, A. P. D., Piccoli, T., Cavion, G., Lukrafka, J. L., \& Ferrari, R. S. (2020). Hospital physical therapy management in pediatric patients with covid-19: Case reports. Revista Paulista de Pediatria, 39(July 2020). https://doi.org/10.1590/1984-0462/2021/39/2020238

Sharma, P., Arora, S., Sarkar, S., \& Puliyel, J. (2016). A randomized clinical trial to assess the effectiveness of prone position on cardiorespiratory outcomes among infants with respiratory distress. MAMC 
Journal of Medical Sciences, 2(2), 81 https://doi.org/10.4103/2394-7438.182725

Shepherd, K. L., Yiallourou, S. R., Odoi, A., Brew, N., Yeomans, E., Willis, S., Horne, R. S. C., \& Wong, F. Y. (2019). Effects of prone sleeping on cerebral oxygenation in preterm infants. Journal of Pediatrics, 204, 103-110.e1. https://doi.org/10.1016/j.jpeds.201 8.08.076

UNICEF. (2019). Levels \& Trends in Child Mortality: Report 2019-Estimates developed by the UN Inter-agency Group for Child Mortality Estimation. Unicef/Who/Wb/Un, 1-32. https://doi.org/10.1371/ journal.pone. 0144443
Utario, Y., Rustina, Y., \& Waluyanti, F. T. (2017). The quarter prone position increases oxygen saturation in premature infants using continuous positive airway pressure. Comprehensive Child and Adolescent Nursing, 40(1), 95-101. https://doi.org/10.1080/2469 4193.2017.1386976

Yin, T., Yuh, Y. S., Liaw, J. J., Chen, Y. Y., \& Wang, K. W. K. (2016). Semi-prone position can influence variability in respiratory rate of premature infants using nasal CPAP. Journal of Pediatric Nursing, 31(2), e167-e174. https://doi.org/10.1016/j.pedn.201 5.10 .014 